tion. If this were the case, then lowering the surface tension of the atomizer solution should cause the particle size to decrease; this effect has also been observed in the present work in experiments in which the chromic acid was made up in acetone and water mixtures.

The fate of a droplet bathed in flame gases may be visualized as one of rapid contraction of a spherical shape, the centre at least of which may retain a trace of solvent until contraction can no longer take place. At this stage, the temperature of the surface rises particularly rapidly by both physical and heterogeneous chemical processes, causing the particle to solidify, melt or vaporize (depending on temperature). Decrepitation might then result if the last traces of solvent were to cause particles which are molten on the surface to explode. Fig. 2 shows strikingly such a particle at the instant of disintegration.

We thank Dr R. P. Ferrier, of the Cavendish Laboratory, Cambridge, for helpful advice on electron microscope techniques. The instrument used was an AEI, type EM6, made available by the Department of Metallurgy.

R. KeLly

P. J. PADLEY

Department of Chemistry,

University College of Swansea.

Received September 18, 1967.

${ }^{1}$ Padley, P. J., thesis Univ. Cambridge (1959).

${ }^{2}$ Dobbins, R. A., Eleventh Symposium (International) on Combustion (Berkeley, 1966),

${ }^{3}$ Nielsen, M. L., Hamilton, P. M., and Walsh. R. J., in Ultrafine Particles (edit. by Kuhn, Lamprey and Sheer), 181 (Wiley, NY, 1963).

4 Mavrodineanu, R., and Boiteux, H., in Flame Spectroscopy, 94 (Wiley, NY, 1965).

\section{Comments on Effect of Vibrations on the Transition Regime in Pipe Flow}

THE results recently reported by James and Morton ${ }^{1}$ disagree with results which I obtained in 1951 in research supported by the US Office of Naval Research. My work actually covered the effects of transverse and longitudinal vibrations on flow in circular tubes over a range of Reynolds numbers from 750 to a little more than 10,000 , including the transition regime. I concluded that vibra. tion had no effect on the friction factor except that at Reynolds numbers above about 2,200 flow which was laminar without vibration became turbulent with certain types of vibration. (Laminar flow was obtained to a Reynolds number of about 15,000 in the apparatus using a special head tank and water as fluid.)

My tests in the transition regime delineated by James and Morton were made in an aluminium alloy tube (12 ft. long, $0 \cdot 5 \mathrm{in}$. outside diameter, $0 \cdot 065 \mathrm{in}$. wall thickness), using chiefly aircraft hydraulic oil as fluid. The tube was clamped near both ends to give fixed end conditions about $9 \mathrm{ft} .2 \mathrm{in}$. apart. Piezometer taps were located $11.5 \mathrm{ft}$. apart, outside the clamps. The taps were carefully deburred by reaching in from the ends of the tube. An entrance length of about 30 in. was joined smoothly to the upstream end. A heat exchanger was provided to maintain constant temperature.
Table 2. VIBRATIŨN PROGKAMMES (VIBRATORS APPLIED AT CENTRE BETWEEX

\begin{tabular}{|c|c|c|c|c|c|c|c|}
\hline \multirow{2}{*}{$\underset{\substack{\text { Freq. } \\
(\mathrm{c} / \mathrm{s})}}{ }{ }^{A}$} & \multicolumn{2}{|c|}{ Magnetic vibrator } & \multicolumn{2}{|c|}{ VDAMTS } & \multicolumn{2}{|c|}{ Hydraulic vibrato } & \multirow{2}{*}{$\begin{array}{l}\text { Reson- } \\
\text { ance }\end{array}$} \\
\hline & (inp.) & & $\begin{array}{l}\text { Reson- } \\
\text { ance }\end{array}$ & $\begin{array}{l}\text { Freq. } \\
(\mathrm{c} / \mathrm{s})\end{array}$ & $\begin{array}{l}\text { Amp. } \\
\text { (in.) }\end{array}$ & & \\
\hline 0 & 0 & 0 & - & 0 & 0 & 0 & - \\
\hline $23 \cdot 3$ & $0 \cdot 188$ & 1 & Yes & $8 \cdot 3$ & 0.031 & 1 & No \\
\hline $35 \cdot 0$ & $0 \cdot 032$ & 1 & No & $16 \cdot 7$ & 0.031 & 1 & No \\
\hline $46 \cdot 7$ & $0 \cdot 125$ & 3 & Yes & $25 \cdot 0$ & 0.050 & 1 & No \\
\hline $70 \cdot 0$ & 0.020 & 3 & No & $31 \cdot 7$ & 0.250 & 1 & Yes \\
\hline $93 \cdot 3$ & 0.093 & 3 & Yes & $40 \cdot 0$ & $0 \cdot 031$ & 1 & No \\
\hline $160 \cdot 0$ & 0.015 & 5 & No & $50 \cdot 0$ & 0.031 & 3 & No \\
\hline $187 \cdot 0$ & 0.063 & 5 & Yes & $58 \cdot 3$ & 0.031 & 3 & No \\
\hline $250 \cdot 0$ & $0 \cdot 010$ & ? & No & 0 & 0 & 0 & - \\
\hline $333 \cdot 0$ & $0 \cdot 010$ & $?$ & No & & & & \\
\hline 0 & 0 & 0 & & & & & \\
\hline
\end{tabular}

Amplitudes are half the peak to peak displacement.

The experiments consisted essentially of establishing a given flow condition without vibration and measuring the discharge, pressure drop and temperature for that condition. Then, a programme of transverse vibration was followed noting the changes, if any, in the quantities. No changes were observed for any flow condition (except in a series of tests with water at Reynolds numbers above 2,200 , as already noted). A typical set of data for aircraft hydraulic oil $(A N-O-366)$ is quoted in Table 1 and vibration conditions are described in Table 2.

\section{E. Silberman}

St Anthony Falls Hydraulic Laboratory,

University of Minnesota.

Received June 29, 1967.

${ }^{1}$ James, D. D., and Morton, A. S., Nature, 214, 692 (196i).

\section{CHEMISTRY}

\section{Variations in Ozone Formation across the Ozonizer Discharge Gap}

I HAVE studied, by means of the planar ozonizers with quartz windows, described previously ${ }^{1}$, the variations in the formation rate of ozone in the discharge gap. Double-glass and metal-glass ozonizers with $3 \mathrm{~mm}$ gaps were used with dried air and oxygen at a pressure of $760 \mathrm{~mm}$ of mercury and in the temperature range $20^{\circ}-$ $25^{\circ} \mathrm{C}$.

A beam of radiation of wavelength $2537 \AA$, which is heavily absorbed by ozone, traverses the discharge gap with its axis parallel to the ozonizer electrodes, and a movable slit, $0.16 \mathrm{~mm}$ wide, selects the radiation which has passed through a known region of the gap. This radiation reaches a quartz-window photomultiplier with a dielectric filter transmitting at $2537 \AA$ and the output voltage of the photomultiplier controls one beam of a cathode ray oscillograph to indicate ozone concentration in the chosen region. A single-shot time base is used which is triggered either by the discharge or a few milliseconds before discharge. The other beam indicates the ozonizer current; typical oscillograms are shown in Fig. 1. The first three half-cycles of a discharge are usually unsteady. and in doducing formation rates later half-cycles, usuallyfrom the sixth to the twelfth, were used. To find the formation rate in a half-cycle from the oscillogram, a correction for diffusion is made by using the slope in the quiescent part of the half-cycle. A corroction is also

Table 1. TYPICAL MEASUREMUNTS IN TRANSITION REgLME USING AIRCRAFT HYDRAULiC OLL (AN-O-366)

\begin{tabular}{|c|c|c|c|c|c|c|c|c|c|}
\hline $\begin{array}{l}\text { Reynolds } \\
\text { number }\end{array}$ & $\begin{array}{l}\text { Vibration } \\
\text { programme }\end{array}$ & $\begin{array}{l}A p\left(\mathrm{lb} . / \mathrm{in}^{2} \mathrm{ft}^{-1}\right. \\
\text { measured }\end{array}$ & $\begin{array}{c}\Delta p \text { calculated } \\
\text { for laminar flow }\end{array}$ & $\lambda$ & $\begin{array}{l}\text { Effect of } \\
\text { vibration }\end{array}$ & $\underset{\left({ }^{\circ} \mathrm{F}\right)}{\text { Temp. }}$ & $\begin{array}{c}\text { Mean pressure } \\
\text { (lb./in. above } \\
\text { atmos.) }\end{array}$ & $\begin{array}{c}\text { Kinematic } \\
\text { viscosity* } \\
\left(\mathrm{ft} .{ }^{2} / \sec \times 10^{4}\right)\end{array}$ & $\begin{array}{l}\text { Unit weight } \\
\left.\text { (lb. } / \mathrm{ft}^{3}\right)^{3}\end{array}$ \\
\hline $\begin{array}{l}1460 \\
1530 \\
1960 \\
2120 \\
1950 \\
2110\end{array}$ & $\begin{array}{l}A \\
B \\
B \\
B \\
A \\
A\end{array}$ & $\begin{array}{r}0.826 \\
0.958 \\
1.390 \\
1.480 \\
1.390 \\
1.480\end{array}$ & $\begin{array}{r}0.858 \\
1.030 \\
1.400 \\
1.510 \\
1.395 \\
1.510\end{array}$ & $\begin{array}{l}0 \cdot 042 \\
0 \cdot 0406 \\
0 \cdot 0323 \\
0 \cdot 0294 \\
0 \cdot 0326 \\
0 \cdot 0297\end{array}$ & $\begin{array}{l}\text { None } \\
\text { None } \\
\text { None } \\
\text { None } \\
\text { None } \\
\text { None }\end{array}$ & $\begin{array}{l}74 \\
70 \\
70 \\
70 \\
70 \\
70\end{array}$ & $\begin{array}{r}78 \\
91 \\
134 \\
150 \\
135 \\
148\end{array}$ & $\begin{array}{l}2 \cdot 17 \\
2 \cdot 38 \\
2 \cdot 40 \\
2 \cdot 40 \\
2 \cdot 40 \\
2 \cdot 40\end{array}$ & $\begin{array}{l}53 \cdot 0 \\
53 \cdot 1 \\
53 \cdot 1 \\
53 \cdot 1 \\
53 \cdot 1 \\
53 \cdot 1\end{array}$ \\
\hline
\end{tabular}

* Determined by Engler viscosimeter at atmospheric pressure and corrected to mean pressure by adding 1.5 per cent for each $100 \mathrm{lb}$./in. ${ }^{2}$ above atmospheric pressure. 